\title{
Spectrophotometric determination of ofloxacin in pharmaceuticals and human urine
}

\author{
K B Vinay, H D Revanasiddappa, M R. Divya and N. Rajendraprasad* \\ Department of Studies in Chemistry, Manasagangothri, University of Mysore, India-570006 \\ *Corresponding e-mail: basavaiahk@yahoo.co.in
}

\begin{abstract}
Three simple and sensitive spectrophotometric methods are described for the determination of ofloxacin (OFX) in pharmaceuticals and in spiked human urine. First and second methods are based on the measurement of absorbance of OFX in $0.1 \mathrm{M} \mathrm{HCl}$ at $293 \mathrm{~nm}$ (method A) and $0.1 \mathrm{M} \mathrm{NaOH}$ at $287 \mathrm{~nm}$, respectively. The third method is based on the measurement of 2:1 complex formed between OFX and iron(III) in $\mathrm{H}_{2} \mathrm{SO}_{4}$ medium, the complex peaking at 420 $\mathrm{nm}(\operatorname{method} \mathrm{C})$. The optimum conditions for all the three methods are optimized. Beer's law is obeyed over the ranges 0.63-12.5 using method $\mathrm{A}$ and method $\mathrm{B}$, and $10-120 \mu \mathrm{g} \mathrm{mL}^{-1} \mathrm{using}$ method $\mathrm{C}$. The apparent molar absorptivity values are calculated to be $3.5 \times 10^{4}, 2.76 \times 10^{4}$ and $2.51 \times 10^{3} \mathrm{~L} \mathrm{~mol}^{-1} \mathrm{~cm}^{-1}$ for method $\mathrm{A}$, method $\mathrm{B}$ and method $\mathrm{C}$, respectively. The Sandell sensitivity, limit of detection (LOD) and limit quantification (LOQ) values are also reported. All the methods were validated in accordance with current ICH guidelines. The developed methods were employed with high degree of precision and accuracy for the estimation of total drug content in commercial tablet formulations of DOX. The results obtained from human spiked urine are satisfactory and recovery values are in the range $95.5-106.6 \%$.
\end{abstract}

Keywords: Ofloxacin; determination; spectrophotometry; pharmaceuticals; spiked urine.

\section{Introduction}

Ofloxacin (OFX), a new synthetic second generation fluoroquinolone antibiotic with a broad spectrum of activity against gram-positive and gram-negative bacteria [1]. It is chemically known as $(R S)$-7-fluoro-2-methyl-6-(4-methylpiperazin-1-yl)-10-oxo-4-oxa-1-azatricyclo[7.3.1.0 $\left.0^{5,13}\right]$ trideca-5(13),6,8,11-tetraene-11-carboxylic acid (Fig 1).<smiles>CC1COc2c(N3CCN(C)CC3)c(F)cc3c(=O)c(C(=O)O)cn1c23</smiles>

Figure 1. Chemical structure of OFX.

Several methods for the determination of OFX in pharmaceuticals or/and in urine are found in the literature including fluorimetric $[2,3]$, chromatographic [4-15], electrophoretic [16-18], electroanalytical [19-23], chemiluminescence flow 
injection analysis [24-29] and bioassay [30]. In some Pharmacopoeias OFX has been determined [31-33] by non-aqueous titrimetric procedure.

Spectrophotometry is characterized by its speed and simplicity, accuracy and inexpensive instrument needed, and hence it is an important alternative to other analytical methods, with clear advantages in terms of cost of analysis. Inspite of its simplicity and versatility, no UV-spectrophotometric method has ever been reported for OFX.
Several visible spectrophotometric methods [3440] employing different reactions have been reported for the assay of OFX either alone or with some other therapeutic agents. However, the reported spectrophotometric methods, though sensitive, suffer from one or the other disadvantage such as use of boiling or extraction step, strict $\mathrm{pH}$ control, use of organic solvent/expensive chemical and measurement of less sensitive species (Table 1).

Table 1. Comparison of the performance characteristics of the present methods with the published methods.

\begin{tabular}{|c|c|c|c|c|c|c|}
\hline $\begin{array}{l}\text { Sl. } \\
\text { No. }\end{array}$ & Reagent/s used & Methodology & $\begin{array}{l}\lambda_{\max } \\
(\mathbf{n m})\end{array}$ & $\begin{array}{c}\text { Linear range }(\mu \mathrm{g} \\
\left.\mathrm{mL}^{-1}\right)\end{array}$ & Remarks & Ref \\
\hline 1 & $\begin{array}{l}\text { Citric acid-acetic } \\
\text { anhydride }\end{array}$ & $\begin{array}{c}\text { Pink colored chromogen } \\
\text { measured }\end{array}$ & 552.5 & $\begin{array}{c}5-55 \\
\left(\varepsilon=6.04 \times 10^{3}\right)\end{array}$ & $\begin{array}{l}\text { Boiling for } 20 \mathrm{~min} \\
\text { required. }\end{array}$ & 34 \\
\hline \multirow[t]{3}{*}{2} & a) Bromophenol blue & \multirow{3}{*}{$\begin{array}{l}\text { Yellow chloroform } \\
\text { extractable 1:1ion-pair } \\
\text { complex complex } \\
\text { was measured }\end{array}$} & 410 & $\begin{array}{c}5-25 \\
\left(\varepsilon=1.04 \times 10^{4}\right)\end{array}$ & \multirow{3}{*}{$\begin{array}{l}\text { Ion-pair formation } \\
\text { and extraction is } \mathrm{pH} \\
\text { dependent, extraction } \\
\text { step involved, organic } \\
\text { solvent is used, } \\
\text { narrow linear range. }\end{array}$} & \multirow{3}{*}{35} \\
\hline & b) Bromothymol blue & & 415 & $\begin{array}{c}2-15 \\
\left(\varepsilon=2.01 \times 10^{4}\right)\end{array}$ & & \\
\hline & c)Bromocresol purple & & 410 & $\begin{array}{c}2-20 \\
\left(\varepsilon=1.04 \times 10^{4}\right)\end{array}$ & & \\
\hline \multirow[t]{2}{*}{3} & $\begin{array}{l}\text { a) Tropaeolin } 000(\mathrm{TP} \\
000)\end{array}$ & $\begin{array}{l}\text { Red chloroform } \\
\text { extractable ion-pair } \\
\text { complex measured }\end{array}$ & 485 & $\begin{aligned} & 2.5-30 \\
(\varepsilon= & \left.8.24 \times 10^{3}\right)\end{aligned}$ & \multirow{2}{*}{$\begin{array}{l}\text { Ion-pair formation } \\
\text { and extraction is } \mathrm{pH} \\
\text { dependent, extraction } \\
\text { step involved, organic } \\
\text { solvent is used, } \\
\text { narrow linear range. }\end{array}$} & \multirow{2}{*}{36} \\
\hline & $\begin{array}{l}\text { b) Supracene Violet 3B } \\
\text { (SV 3B) }\end{array}$ & $\begin{array}{l}\text { Chloroform extractable } \\
\text { ion-pair complex } \\
\text { measured }\end{array}$ & 575 & $\begin{aligned} & 2.5-25 \\
(\varepsilon= & \left.1.09 \times 10^{4}\right)\end{aligned}$ & & \\
\hline 4 & Iron(III) nitrate & $\begin{array}{c}\text { Ambered coloured } \\
\text { complex was measured }\end{array}$ & 370 & $\begin{array}{c}0-62.5 \\
\left(A_{1 \%}=207\right)\end{array}$ & Buffers used. & 37 \\
\hline 5 & Iron(III) chloride/HCl & Yellow complex measured & 410 & $20-160$ & $\begin{array}{l}\text { Less sensitive, } \\
\text { significant blank } \\
\text { absorbance. }\end{array}$ & 38 \\
\hline 6 & Iron(III) alum/ $\mathrm{H}_{2} \mathrm{SO}_{4}$ & Yellow complex measured & 420 & $1.8-289$ & $\begin{array}{l}\text { Flow-injection } \\
\text { analysis assembly } \\
\text { required. }\end{array}$ & 39 \\
\hline 7 & $\mathrm{Ce}(\mathrm{IV})-\mathrm{MBTH}$ & $\begin{array}{l}\text { Oxidative coupling } \\
\text { reaction product measured }\end{array}$ & 640 & $1-10$ & $\begin{array}{l}\text { Uses expensive } \\
\text { reagent, less stable } \\
\text { species measured. }\end{array}$ & 40 \\
\hline \multirow[t]{3}{*}{8} & a) $0.1 \mathrm{M} \mathrm{HCl}$ & $\begin{array}{c}\text { UV spectrophotometric } \\
\text { detection }\end{array}$ & 293 & $\begin{array}{c}\mathbf{0 . 6 3 - 1 2 . 5} \\
\left(\varepsilon=3.5 \times 10^{4}\right)\end{array}$ & $\begin{array}{l}\text { Very simple, } \\
\text { sensitive and }\end{array}$ & \multirow[b]{3}{*}{$\begin{array}{c}\text { Present } \\
\text { work }\end{array}$} \\
\hline & b) $0.1 \mathrm{~N} \mathrm{NaOH}$ & $\begin{array}{c}\text { UV spectrophotometric } \\
\text { detection }\end{array}$ & 287 & $\begin{array}{c}\mathbf{0 . 6 3 - 1 2 . 5} \\
\left(\varepsilon=2.76 \times 10^{4}\right)\end{array}$ & $\begin{array}{l}\text { precise. No heating } \\
\text { /extraction involved. } \\
\text { Free from critical }\end{array}$ & \\
\hline & $\begin{array}{l}\text { c) iron(III) ammonium } \\
\text { sulphate-acid medium }\end{array}$ & $\begin{array}{l}\text { Yellow complex } \\
\text { measured }\end{array}$ & 420 & $\begin{array}{c}\mathbf{1 0 - 1 2 0} \\
\left(\varepsilon=2.51 \times 10^{3}\right)\end{array}$ & $\begin{array}{l}\text { experimental } \\
\text { variables. Highly } \\
\text { stable coloured } \\
\text { specied measured } \\
\text { (visible method), } \\
\text { Wide linear dynamic } \\
\text { ranges. }\end{array}$ & \\
\hline
\end{tabular}

$\varepsilon=$ molar absorptivity in mol $1-1 \mathrm{~cm}-1$. 
There is a need for methods that are simple, precise, accurate and fast for the routine determination of OFX. This study describes the development and validation of two UV- and one visible-spectrophotometric methods for the determination of OFX in bulk drug, tablets and in spiked human urine. The UV-methods are based on the measurement of the absorbance of OFX solution either in $0.1 \mathrm{~N} \mathrm{HCl}$ at $293 \mathrm{~nm}(\operatorname{method} \mathrm{A})$ or in $0.1 \mathrm{~N} \mathrm{NaOH}$ at $287 \mathrm{~nm}$ (method B). The visible spectrophotometric method (method C) is based on the measurement of yellow complex, peaking at $420 \mathrm{~nm}$ formed between OFX and iron(III) in $\mathrm{H}_{2} \mathrm{SO}_{4}$ medium. Different iron(III) salts have previously been employed for the assay of OFX in pharmaceuticals. The method using iron(III) nitrate nanohydrate [37] has not been validated as per the current $\mathrm{ICH}$ guidelines. Mathur et al [38] have used iron(III) chloride in $\mathrm{HCl}$ medium as the chromogenic agent where the reagent blank is found to exhibit significant absorbance at the wavelength of measurement $(410 \mathrm{~nm})$. The method using iron(III) alum [39] as a reagent, though has a wide linear dynamic range and has been applied for spiked urine sample lacks the simplicity required for routine analysis since it requires a flow-injection analysis assembly. The proposed method using iron(III) alum overcomes most of the limitations of the existing visible spectrophotometric methods and has been optimized for the experimental variables involved and validated for linearity, sensitivity, selectivity, robustness and ruggedness besides intra-day and inter-day precision and accuracy.

\section{Experimental}

Apparatus

Shimadzu Pharmaspec 1700 UV/Visible and Systronics model 106 digital spectrophotometers with $1 \mathrm{~cm}$ path length quartz cells were used for absorbance measurements.

Reagents and Solutions

All chemicals used were of analytical reagent grade. Distilled water was used throughout the investigation.
Hydrochloric acid $(0.1 \mathrm{M})$ : Prepared by successive dilution of concentrated acid (S.D. Fine Chem, Mumbai, India, sp. gr. 1.18) with water.

Sodium hydroxide $(0.1 \mathrm{~N})$ : One g of pure $\mathrm{NaOH}$ (S.D. Fine Chem, Mumbai, India) was dissolved in water and diluted to $250 \mathrm{~mL}$.

Sulphuric acid $(0.05$ and $0.01 \mathrm{M})$ : Concentrated acid (S.D. Fine Chem, Mumbai, India, sp. gr. 1.84) was diluted appropriately with water to get 0.05 and $0.01 \mathrm{M}$ solutions.

Iron(III) solution: A $0.5 \%$ iron(III) alum solution was prepared by dissolving $1.25 \mathrm{~g}$ of pure ammonium iron(III) sulphate (S.D. Fine Chem, Mumbai, India) in $0.05 \mathrm{M} \mathrm{H}_{2} \mathrm{SO}_{4}$ and diluting to volume with the same acid in a $250 \mathrm{~mL}$ calibrated flask.

Urine: Sample was collected from healthy volunteers (around 25-year-old female and 32-year-old male) and kept frozen until use after gentle thawing.

Pure OFX (Pharmaceutical grade) sample was kindly provided by Cipla India Ltd, India, as a gift and used as received. Two brands of tablets, namely, OF 400 (J.B Chemicals and Pharmaceuticals Ltd, Mumbai, India) and Zenflox 400 (Mankind Pharma Pvt Ltd, New Delhi, India) were used in the investigation.

Standard drug solutions of $25 \mu \mathrm{g} \mathrm{mL}^{-1}$ each in $0.1 \mathrm{M} \mathrm{HCl}$ and $0.1 \mathrm{~N} \mathrm{NaOH}$ for method $\mathrm{A}$, and method $\mathrm{B}$, respectively, and $200 \mu \mathrm{g} \mathrm{mL}^{-1}$ in 0.01 $\mathrm{M} \mathrm{H}_{2} \mathrm{SO}_{4}$ for method $\mathrm{C}$ were prepared by dissolving the calculated quantities of pure OFX in the specified solvents.

\section{General Procedures}

\section{Method A}

Varying aliquots $(0.25,0.5,1.0,2,0,3.0$, 4.0 and $5.0 \mathrm{~mL}$ of $25 \mu \mathrm{g} \mathrm{mL}^{-1}$ in $0.1 \mathrm{M} \mathrm{HCl}$ ) of standard solution corresponding to $0.625-12.5 \mu \mathrm{g}$ $\mathrm{mL}^{-1}$ OFX were taken into a series of $10 \mathrm{~mL}$ volumetric flasks, the content was diluted to the mark with the same solvent and mixed well. The absorbance of each solution was then measured at 293 against $0.1 \mathrm{M} \mathrm{HCl}$. 


\section{Method B}

Into a series of $10 \mathrm{~mL}$ calibration flasks, aliquots of OFX standard solution $\left(25 \mu \mathrm{g} \mathrm{mL}^{-1}\right.$ in $0.1 \mathrm{~N} \mathrm{NaOH}$ ) equivalent to $0.63-12.5 \mu \mathrm{g} \mathrm{mL}^{-1}$ OFX were accurately measured and transferred, and volume was made up to mark with $0.1 \mathrm{~N}$ $\mathrm{NaOH}$. After mixing the content, the absorbance of each solution was measured at $287 \mathrm{~nm} v s 0.1$ $\mathrm{N} \mathrm{NaOH}$

\section{Method C}

Different aliquots $(0.0-6.0 \mathrm{~mL})$ of OFX $\left(200 \mu \mathrm{g} \mathrm{mL}^{-1}\right)$ were accurately measured into a series of $10 \mathrm{~mL}$ calibrated flasks by means of microburette and the total volume was adjusted to $6.0 \mathrm{~mL}$ with $0.01 \mathrm{M} \mathrm{H}_{2} \mathrm{SO}_{4}$. To each flask, $2 \mathrm{~mL}$ of $0.5 \%$ iron(III) alum solution was added. The content was mixed and allowed to stand for 5 minutes and then diluted to $10 \mathrm{~mL}$ with water. After mixing well, the absorbance was measured at 420 $\mathrm{nm}$ against the reagent blank.

In all three methods, calibration curves were prepared and the concentration of the unknown was read from the calibration graph or computed from the respective regression equation derived using absorbance-concentration data.

\section{Procedure for tablets}

\section{Method A}

Twenty tablets were weighed and pulversized. A quantity of tablet powder containing 10 $\mathrm{mg}$ of OFX was transferred into a $100 \mathrm{~mL}$ volumetric flask. The content was shaken well with about $50 \mathrm{~mL}$ of $0.1 \mathrm{M} \mathrm{HCl}$ for $20 \mathrm{~min}$. The mixture was diluted to the mark with the same acid. It was filtered using Whatmann No 42 filter paper. First $10 \mathrm{~mL}$ portion of the filtrate was discarded. A suitable aliquot of the subsequent portion was diluted to get $25 \mu \mathrm{g} \mathrm{mL}^{-1}$ working concentration and subjected to analysis following the procedure described earlier.

\section{Method B}

Tablet powder equivalent to $10 \mathrm{mg}$ of OFX was transferred into a $100 \mathrm{~mL}$ volumetric flask. The content was shaken well with about $50 \mathrm{~mL}$ of $0.1 \mathrm{~N} \mathrm{NaOH}$ for 20 min and diluted to the mark with $0.1 \mathrm{~N} \mathrm{NaOH}$. It was filtered using Whatmann No. 42 filter paper. First $10 \mathrm{~mL}$ portion of the filtrate was discarded and subsequent portion was analyzed after dilution to $25 \mu \mathrm{g} \mathrm{mL}^{-1}$ OFX with $0.1 \mathrm{~N} \mathrm{NaOH}$.

\section{Method C}

An accurately weighed portion of the tablet powder, equivalent to $20 \mathrm{mg}$ of the drug was shaken with about $50 \mathrm{~mL}$ of $0.01 \mathrm{M} \mathrm{H}_{2} \mathrm{SO}_{4}$ in a $100 \mathrm{~mL}$ standard flask for $20 \mathrm{~min}$. The mixture was diluted to the mark with $0.01 \mathrm{M} \mathrm{H}_{2} \mathrm{SO}_{4}$, mixed well and then filtered through a Whatmann No.42 filter paper. First $10 \mathrm{~mL}$ portion of the filtrate was discarded and a convenient aliquot of subsequent portion was analyzed by the general procedure described for pure drug.

\section{Procedure for spiked human urine}

\section{Method A and Method B}

To prepare spiked urine sample, $2.5 \mathrm{mg}$ of the pure OFX and $10 \mathrm{~mL}$ of urine sample were transferred into a separating funnel, mixed well till dissolution was complete. The solution was extracted with three $10 \mathrm{~mL}$ portion of ethyl acetate and the organic layer was collected in a beaker after drying over anhydrous sodium sulphate. The solvent was evaporated to dryness. The resulting residue was reconstituted either in $0.1 \mathrm{M} \mathrm{HCl}$ and diluted to $100 \mathrm{~mL}$ or with $0.1 \mathrm{M} \mathrm{NaOH}$ before diluting to $100 \mathrm{~mL}$ with the same solvent. Then, the analysis was performed as described under general procedure for pure drug by taking 2-3 $\mathrm{mL}$ of the above solution.

Method C

Five mg of the pure OFX was transferred into a $25 \mathrm{~mL}$ volumetric flask and dissolved in 5 $\mathrm{mL}$ of $0.01 \mathrm{M} \mathrm{H}_{2} \mathrm{SO}_{4}$. After the addition of 12.5 $\mathrm{mL}$ of urine, the volume was brought upto the mark with $0.01 \mathrm{M} \mathrm{H}_{2} \mathrm{SO}_{4}$ and mixed well. Two to 
three $\mathrm{mL}$ portion of aliquot was then subjected to analysis as described earlier.

\section{Results and Discussions}

\section{Spectral characteristics}

OFX dissolved either in $0.1 \mathrm{M} \mathrm{HCl}$ or in $0.1 \mathrm{~N} \mathrm{NaOH}$ exhibited an absorption peak at 293 $\mathrm{nm}$ or $287 \mathrm{~nm}$ (Fig 2), and the absorbance at this wavelength was found to be linearly dependent upon the concentration of drug which served as the basis for the quantification of OFX. In both the cases, the corresponding blank solutions showed negligible absorbance. Therefore these wavelengths were used as analytical wavelength throughout the investigation.

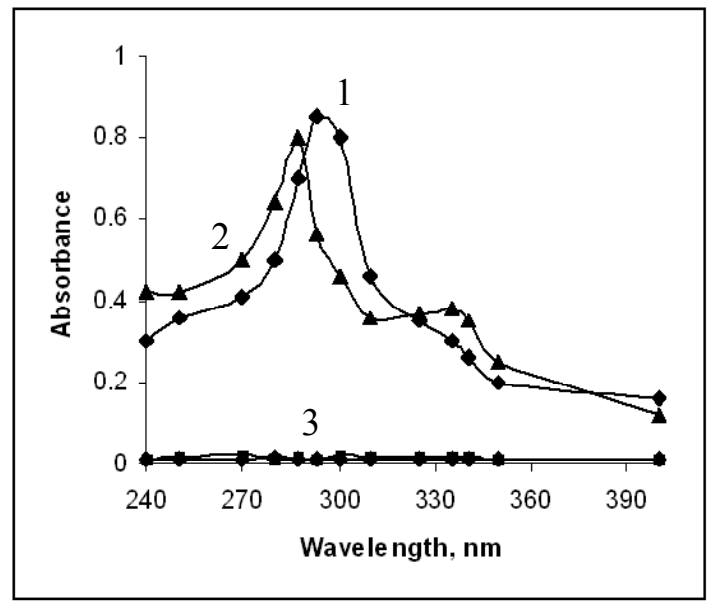

Figure 2. Absorption spectra of: 1. $8.75 \mu \mathrm{g} \mathrm{mL}^{-1}$ OFX in $0.1 \mathrm{~N} \mathrm{HCl}$; 2. $10.5 \mu \mathrm{g} \mathrm{mL}^{-1}$ OFX in $0.1 \mathrm{~N}$ $\mathrm{NaOH}$ and 3. $0.1 \mathrm{~N} \mathrm{HCl}$ and $0.1 \mathrm{~N} \mathrm{NaOH}$.

OFX is reported to react with iron(III) at $\mathrm{pH}$ 3.8 to form a water soluble yellow complex [41]. Preliminary spectrophotometric studies concerning the absorbance of iron(III) and OFX-iron(III) complex solutions in different media (methanol, acetic acid, hydrochloric acid and sulphuric acids) were carried out. The greatest difference between the absorbance of OFX-iron(III) complex and iron(III) solution at the wavelength of maximum absorbance (420 nm) was obtained in $\mathrm{H}_{2} \mathrm{SO}_{4}$ medium. This medium was therefore used for developing a spectrophotometric method for OFX.

Figure 3 shows the absorption spectra in $\mathrm{H}_{2} \mathrm{SO}_{4}$ medium of OFX-iron(III) complex (40 $\mu \mathrm{g}$ $\mathrm{mL}^{-1}$ OFX) (Curve 1) and the blank (Curve 2). As can be seen, iron(III) in $\mathrm{H}_{2} \mathrm{SO}_{4}$ medium shows low absorbance at $420 \mathrm{~nm}$ at which OFX doesnot absorb. This wavelength was selected for further studies.

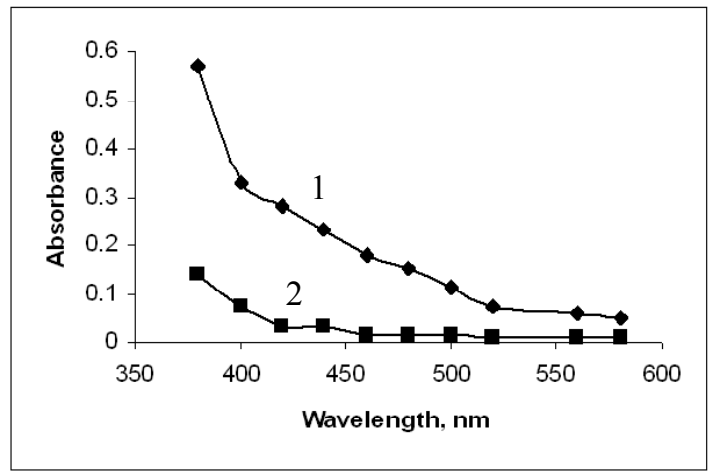

Figure 3. Absorption spectra of: 1. OFX-iron(III) complex $\left(40 \mu \mathrm{g} \mathrm{mL}^{-1} \mathrm{OFX}\right)$ and 2. iron(III) in sulphuric acid.

\section{Method optimization}

\section{Method C}

\section{Effect of iron(III) solution}

The effect of iron(III) concentration on the formation of OFX-iron(III) complex was investigated by varying the volume of iron(III) solution, and using a fixed amount of drug. The results revealed that the complex formation was unaffected in the range of $1-4.0 \mathrm{~mL}$ of $0.5 \%$ iron(III) solution in a total volume of $10 \mathrm{~mL}$. Hence, $2 \mathrm{~mL}$ of $0.5 \%$ iron(III) solution was used throughout the investigation. 
Effect of sulphuric acid concentration on OFXiron(III) complex formation

The effect of $\mathrm{H}_{2} \mathrm{SO}_{4}$ concentration on the complex formation was studied by adding various amounts of $2 \mathrm{M}$ sulphuric acid $(0-4 \mathrm{~mL})$ to a fixed amount of the drug solution before mixing with iron(III) solution. The results revealed that complex formation, sensitivity and stability were unaffected in the concentration range studied. Therefore, no additional sulphuric acid was used in the investigation. This study revealed that $\mathrm{pH}$ has no effect on the complex and its sensitivity as well as stability.

\section{Reaction time and stability of the complex}

The effect of reaction time after adding iron(III) solution and diluting to the mark with water was studied. The colour formation was complete in $5 \mathrm{~min}$ and stable upto $60 \mathrm{~min}$ thereafter.

\section{Composition of OFX -iron(III) complex}

The composition of the OFX-iron(III) complex was studied using Job's continuous variations method [42]. Drug and iron(III) solutions of 1.36 x $10^{-3} \mathrm{M}$ each, were prepared in $0.01 \mathrm{M} \mathrm{H}_{2} \mathrm{SO}_{4}$ and $0.05 \mathrm{M} \mathrm{H}_{2} \mathrm{SO}_{4}$, respectively, and mixed in various molar ratios (with a total volume of $5 \mathrm{~mL}$ ) in $10 \mathrm{~mL}$ volumetric flasks. After $5 \mathrm{~min}$, the solutions were made upto mark, mixed well and the absorbance was subsequently measured at $420 \mathrm{~nm}$. The graph of the results obtained (fig. 4) gave a maximum at a molar ratio of $X_{\max }=0.666$ which indicated the formation of a 2:1 (OFX:iron(III)) complex as shown in figure 5 . The formation constant $\left(\mathrm{K}_{\mathrm{f}}\right)$ of the complex was also calculated from the continuous variation data using the following equation [43]:

$$
K_{f}=\frac{A / A_{m}}{\left[1-A / A_{m}\right]^{n+2} C_{M}(n)^{n}}
$$

where A and Am are the observed maximum absorbance and the absorbance value when all the drug present is complexed, respectively. $\mathrm{C}_{M}$ is the molar concentration of drug at the maximum absorbance and $\mathrm{n}$ is the stoichiometry with which iron(III) complexes with drug. The $\log \mathrm{K}_{\mathrm{f}}$ value was found to be 5.65 .

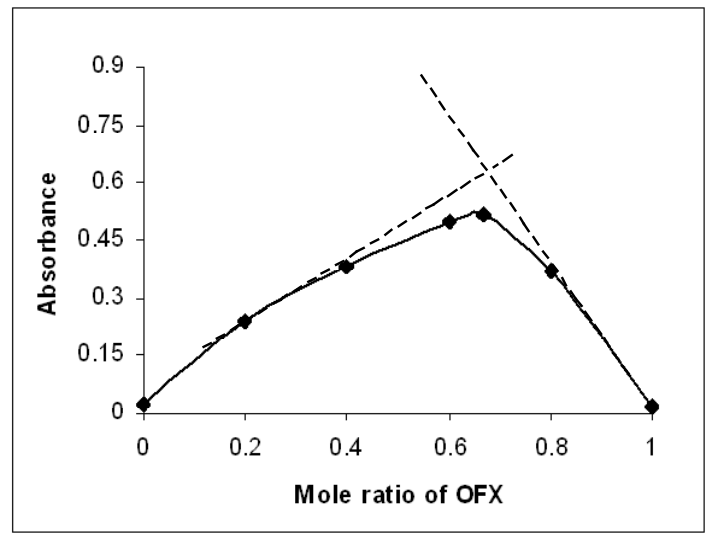

Figure 4. Continuous variation plot for OFXiron(III) complex.<smiles>CC1COc2c(N3CCN(C)CC3)c(F)cc3c(=O)c(OC(=O)C4=CN5c6c(cc(F)c(N7CCN(C)CC7)c6OC4)OC5(O)O)cn1c23</smiles>

Figure 5. Probable structure of the OFX-iron(III) complex.

\section{Method Validation}

Linearity, sensitivity, limits of detection and quantification

A linear correlation was found between absorbance at $\lambda_{\max }$ and concentration of OFX in the 
ranges given in Table 2. The graphs are described by the regression equation:

$$
\mathrm{Y}=\mathrm{a}+\mathrm{bX}
$$

(where Y - absorbance of 1-cm layer of solution; $\mathrm{a}$ - intercept; $\mathrm{b}$ - slope and X - concentration in $\left.\mu \mathrm{g} \mathrm{mL}^{-1}\right)$. Regression analysis of the Beer's law data using the method of least squares was made to evaluate the slope (b), intercept (a) and correlation coefficient ( $r$ ) for each system and the values are presented in Table 2. The optical characteristics such as Beer's law limits, molar absorptivity and Sandell sensitivity values [44] of all the three methods are also given in Table 2. The limits of detection (LOD) and quantification (LOQ) calculated according to $\mathrm{ICH}$ guidelines [45] using the formulae:

$\mathrm{LOD}=3.3 \mathrm{~S} / \mathrm{b}$ and $\mathrm{LOQ}=10 \mathrm{~S} / \mathrm{b}$, (where $\mathrm{S}$ is the standard deviation of blank absorbance values, and $b$ is the slope of the calibration plot) are also presented in Table 2. The high values of $\varepsilon$ and low values of Sandell sensitivity and LOD indicate the high sensitivity of the proposed methods.

Table 2. Sensitivity and regression parameters.

\begin{tabular}{|c|c|c|c|}
\hline Parameter & Method A & Method B & Method C \\
\hline$\lambda \max , \mathrm{nm}$ & 293 & 287 & 420 \\
\hline Linear range, $\mu \mathrm{g} \mathrm{mL}^{-1}$ & $0.63-12.5$ & $0.63-12.5$ & $10-120$ \\
\hline Molar absorptivity $(\varepsilon), \mathrm{L} \mathrm{mol}^{-1} \mathrm{~cm}^{-1}$ & $3.5 \times 10^{4}$ & $2.76 \times 10^{4}$ & $2.51 \times 10^{3}$ \\
\hline Sandell sensitivity ${ }^{*}, \mu \mathrm{g} \mathrm{cm}^{-2}$ & 0.0103 & 0.0131 & 0.1441 \\
\hline Limit of detection (LOD), $\mu \mathrm{g} \mathrm{mL}^{-1}$ & 0.10 & 0.12 & 2.66 \\
\hline Limit of quantification (LOQ), $\mu \mathrm{g} \mathrm{mL}^{-1}$ & 0.29 & 0.37 & 8.05 \\
\hline \multicolumn{4}{|l|}{ Regression equation, $\mathrm{Y}^{* *}$} \\
\hline Intercept (a) & 0.0033 & 0.0018 & 0.0113 \\
\hline Slope (b) & 0.10 & 0.08 & 0.01 \\
\hline Standard deviation of a $\left(\mathrm{S}_{\mathrm{a}}\right)$ & 0.0998 & 0.0998 & 0.0998 \\
\hline Standard deviation of $b\left(\mathrm{~S}_{\mathrm{b}}\right)$ & 0.0089 & 0.011 & 0.001 \\
\hline Variance $\left(\mathrm{Sa}^{2}\right)$ & 0.01 & 0.01 & 0.01 \\
\hline Regression coefficient $(\mathrm{r})$ & 0.9999 & 0.9999 & 0.9996 \\
\hline
\end{tabular}

*Limit of determination as the weight in $\mu \mathrm{g}$ per $\mathrm{mL}$ of solution, which corresponds to an absorbance of $\mathrm{A}=0.001$ measured in a cuvette of cross-sectional area $1 \mathrm{~cm} 2$ and $1=1 \mathrm{~cm}$.

${ }^{* *} \mathrm{Y}=\mathrm{a}+\mathrm{bX}$, Where $\mathrm{Y}$ is the absorbance, $\mathrm{X}$ is concentration in $\mu \mathrm{g} \mathrm{mL}-1$, a is intercept, $\mathrm{b}$ is slope.

\section{Precision and accuracy}

The assays described under "general procedures" were repeated seven times within the day to determine the repeatability (intra-day precision) and five times on different days to determine the intermediate precision (inter-day precision) of the methods. These assays were performed for three levels of analyte. The results of this study are summarized in Table 3. The percentage relative standard deviation ( $\% \mathrm{RSD}$ ) values were $\leq 1.58 \%$ (intra-day) and $\leq 2.11 \%$ (inter-day) indicating high precision of the methods. Accuracy was evaluated as percentage relative error (RE) between the measured mean concentrations and taken concentrations for OFX. Bias \{bias $\%=[($ Concentration found - known concentration) x 100 / known concentration]\} was calculated at each concentration and these results are also presented in Table 3. Percent relative error ( $\% \mathrm{RE})$ values of $\leq 3.0 \%$ demonstrate the high accuracy of the proposed methods. 
Table 3. Evaluation of intra-day and inter-day accuracy and precision.

\begin{tabular}{|c|c|c|c|c|c|c|c|}
\hline \multirow[b]{2}{*}{ Method } & \multirow[b]{2}{*}{$\begin{array}{c}\text { OFX } \\
\text { taken, } \mu \mathrm{g} \\
\mathrm{mL}^{-1}\end{array}$} & \multicolumn{6}{|c|}{$\begin{array}{l}\text { Intra-day accuracy and precision Inter-day accuracy and precision } \\
(\mathrm{n}=7) \\
(\mathrm{n}=5)\end{array}$} \\
\hline & & $\begin{array}{c}\text { OFX } \\
\text { found } \\
\pm \mathrm{CL}, \mu \mathrm{g} \\
\mathrm{mL}^{-1}\end{array}$ & $\% \mathrm{RE}$ & $\% \mathrm{RSD}$ & $\begin{array}{c}\text { OFX } \\
\text { found } \pm \mathrm{CL}, \\
\mu \mathrm{g} \mathrm{mL}-1\end{array}$ & $\% \mathrm{RE}$ & $\%$ RSD \\
\hline \multirow{4}{*}{ A } & 3.0 & $3.05 \pm 0.02$ & 1.67 & 0.56 & $3.09 \pm 0.07$ & 3.00 & 1.80 \\
\hline & 6.0 & $5.93 \pm 0.04$ & 1.17 & 0.67 & $6.08 \pm 0.12$ & 1.33 & 1.56 \\
\hline & 9.0 & $9.06 \pm 0.08$ & 0.67 & 0.89 & $9.11 \pm 0.22$ & 1.22 & 1.98 \\
\hline & 3.0 & $2.92 \pm 0.02$ & 2.67 & 0.62 & $3.07 \pm 0.06$ & 2.33 & 1.56 \\
\hline \multirow[t]{3}{*}{ B } & 6.0 & $6.08 \pm 0.04$ & 1.33 & 0.79 & $6.11 \pm 0.09$ & 1.83 & 1.22 \\
\hline & 9.0 & $8.95 \pm 0.07$ & 0.56 & 0.82 & $9.10 \pm 0.13$ & 1.11 & 1.11 \\
\hline & 30.0 & $29.4 \pm 0.30$ & 2.00 & 1.11 & $30.6 \pm 0.56$ & 2.00 & 1.48 \\
\hline \multirow[t]{2}{*}{$\mathrm{C}$} & 60.0 & $60.9 \pm 0.69$ & 1.50 & 1.22 & $61.3 \pm 1.44$ & 2.17 & 1.89 \\
\hline & 90.0 & $91.0 \pm 1.33$ & 1.11 & 1.58 & $91.8 \pm 2.40$ & 2.00 & 2.11 \\
\hline
\end{tabular}

\%RE. Percent relative error, \%RSD. relative standard deviation and CL. Confidence limits were calculated from: $\mathrm{CL}= \pm \mathrm{tS} / \sqrt{ } \mathrm{n}$. (The tabulated value of $\mathrm{t}$ is 2.45 and 2.77 for six and four degrees of freedom respectively, at the $95 \%$ confidence level; $\mathrm{S}=$ standard deviation and $\mathrm{n}=$ number of measurements).

\section{Selectivity}

A systematic study was performed to determine the effect of matrix by analyzing the placebo blank and synthetic mixture containing OFX. A placebo blank of the composition: starch (10 $\mathrm{mg})$, acacia (15 mg), hydroxyl cellulose ( $10 \mathrm{mg})$, sodium citrate $(10 \mathrm{mg})$, talc $(20 \mathrm{mg})$, magnesium stearate $(15 \mathrm{mg})$ and sodium alginate $(10 \mathrm{mg})$ was made and its solution was prepared as described under 'tablets', and then subjected to analysis. The absorbance of the placebo solution in each case was almost equal to the absorbance of the blank which revealed no interference. To assess the role of the inactive ingredients on the assay of OFX, a synthetic mixture was separately prepared by adding $20 \mathrm{mg}$ of OFX to the placebo mentioned above. The drug was extracted and solution prepared as described under the general procedure for tablets. The solutions after appropriate dilution wherever necessary were analyzed following the recommended procedures. The absorbance resulting from $10 \mu \mathrm{g} \mathrm{mL}^{-1}$ OFX in method A and method $\mathrm{B}$, and $70 \mu \mathrm{g} \mathrm{mL} \mathrm{mL}^{-1} \mathrm{OFX}$ solution method $\mathrm{C}$, were nearly the same as those obtained for pure OFX solutions of identical concentrations. This unequivocally demonstrated the non-interference of the inactive ingredients in the assay of OFX. Further, the slopes of the calibration plots prepared from the synthetic mixture solutions were about the same as those prepared from pure drug solutions.

\section{Robustness}

The robustness of the method (method C) was evaluated by making small incremental changes in the volume of iron(III) and reaction time, and the effect of the changes was studied by calculating the mean RSD values. The changes had negligible influence on the results as revealed by small intermediate precision values expressed as $\% \operatorname{RSD}(2.66 \%)$. 


\section{Ruggedness}

Method ruggedness was expressed as the RSD of the same procedure applied by four different analysts as well as using four different instruments. The inter-analysts RSD were within $2.89 \%$ whereas the inter-instruments RSD for the same OFX amount was less than about 3\% suggesting that the developed methods were rugged. The results are shown in Table 4.

Table 4. Method robustness and ruggedness expressed as intermediate precision (\% RSD).

\begin{tabular}{|c|c|c|c|c|c|}
\hline \multirow[b]{3}{*}{ Method } & \multirow[b]{3}{*}{ OFX taken* } & \multirow{2}{*}{\multicolumn{2}{|c|}{$\begin{array}{c}\text { Robustness } \\
\text { Parameter altered }\end{array}$}} & \multicolumn{2}{|c|}{ Ruggedness } \\
\hline & & & & \multirow[b]{2}{*}{$\begin{array}{c}\text { Inter-analysts, } \\
(\% \mathrm{RSD}) \\
(\mathrm{n}=4)\end{array}$} & \multirow{2}{*}{$\begin{array}{c}\text { Inter- } \\
\text { instruments, } \\
(\% \mathrm{RSD}) \\
(\mathrm{n}=4)\end{array}$} \\
\hline & & $\begin{array}{l}\text { Volume of } \\
\text { iron(III) } \\
(\% \mathrm{RSD})\end{array}$ & $\begin{array}{c}\text { Reaction } \\
\text { time }^{* *}\end{array}$ & & \\
\hline $\mathrm{A}$ & 10 & - & - & 1.89 & 2.98 \\
\hline B & 10 & - & - & 2.89 & 3.00 \\
\hline $\mathrm{C}$ & 60 & 2.66 & 1.74 & 2.25 & 2.55 \\
\hline
\end{tabular}

*Volumes of iron(III) solution used were 1.8, 2.0 and $2.2 \mathrm{~mL}$. **Reaction times studied were 4, 5 and 6 min.

\section{Analysis of pharmaceutical formulations}

The described procedures were successfully applied to the determination of OFX in its pharmaceutical formulations (OF 400, Zenflox 400). The results obtained (Table 5) were statistically compared with the British Pharmacopoeial method [31]. The method involved the titration of OFX in anhydrous acetic acid with acetous perchloric acid to a potentiometric end point detection. The results obtained by the proposed methods agreed well with those of reference method and with the label claim. The results were also compared statistically by a Student's t-test for accuracy and by a variance F-test for precision [46] with those of the reference method at $95 \%$ confidence level as summarized in Table 5. The results showed that the calculated $t$-and F-values did not exceed the tabulated values inferring that proposed methods are as accurate and precise as the reference method. 
Table 5. Results of analysis of tablets by the proposed methods and statistical comparison of the results with the reference method.

\begin{tabular}{|c|c|c|c|c|c|}
\hline \multirow{3}{*}{$\begin{array}{c}\text { Tablet brand } \\
\text { name }\end{array}$} & \multirow{3}{*}{$\begin{array}{l}\text { Nominal } \\
\text { amount, } \\
\text { (mg/tablet) }\end{array}$} & \multicolumn{4}{|c|}{ Found* (Percent of label claim \pm SD) } \\
\hline & & \multirow{2}{*}{$\begin{array}{c}\text { Reference } \\
\text { method }\end{array}$} & \multicolumn{3}{|c|}{ Proposed methods } \\
\hline & & & Method A & Method B & Method C \\
\hline \multirow{4}{*}{ OF-400 } & \multirow{4}{*}{400} & \multirow{3}{*}{$100.2 \pm 0.89$} & $98.9 \pm 0.98$ & $100.8 \pm 1.5$ & $101.8 \pm 1.8$ \\
\hline & & & $\mathbf{t}=2.19$ & $\mathbf{t}=0.79$ & $\mathbf{t}=1.88$ \\
\hline & & & $\mathbf{F}=1.21$ & $\mathbf{F}=2.84$ & $\mathbf{F}=4.09$ \\
\hline & & \multirow{3}{*}{$101.6 \pm 0.72$} & $99.2 \pm 0.98$ & $102.6 \pm 1.57$ & $102.0 \pm 1.75$ \\
\hline \multirow{2}{*}{ Zenflox 400} & \multirow[t]{2}{*}{400} & & $\mathbf{t}=4.46$ & $\mathbf{t}=1.38$ & $\mathbf{t}=0.51$ \\
\hline & & & $\mathbf{F}=\mathbf{1 . 8 5}$ & $\mathbf{F}=4.75$ & $\mathbf{F}=5.91$ \\
\hline
\end{tabular}

*Average of five determinations.

Tabulated $\mathrm{t}$ value at the $95 \%$ confidence level is 2.77 . Tabulated $\mathrm{F}$ value at the $95 \%$ confidence level is 6.39 .

\section{Application to spiked human urine}

As another application of the proposed methods, recovery from human urine samples was carried out followed by a prior extraction of drug from urine in method A and method B, and treatment of drug with urine without any extraction step in method C. Recovery studies were performed with the sample containing various amounts of OFX. The results of recovery studies (Table 6) revealed that, other constituents present in the urine did not interfere in the method. The recovery values were in the range 95.5$106.6 \%$ with standard deviation of $0.52-1.60$. Ofloxacin is rapidly and efficiently absorbed after oral administration and is eliminated principally by hepatic metabolism and subsequent urinary excretion. The normal dose for adults is $400 \mathrm{mg}$ day $^{-1}$. Ofloxacin undergoes only limited metabolism: nearly $80 \%$ of an orally administered dose is excreted unchanged in urine [17]. The concentration of OFX in urine passed during $24 \mathrm{~h}$ is within the range of OFX determination by the proposed methods. 
Table 6. Application of the proposed methods to the ofloxacin concentration measurements in spiked urine.

\begin{tabular}{|c|c|c|c|}
\hline Method & $\begin{array}{c}\text { OFX added, } \\
\mu \mathrm{g} \mathrm{mL}-1\end{array}$ & $\begin{array}{c}\text { OFX } \\
\text { found }{ }^{*}, \\
\mu \mathrm{g} \mathrm{mL}^{-1}\end{array}$ & $\begin{array}{c}\text { Recovery } \\
\text { of OFX } \\
\text { (Percent } \pm \text { SD) }\end{array}$ \\
\hline \multirow{3}{*}{ A } & 4.0 & 3.82 & $95.5 \pm 0.86$ \\
\hline & 8.0 & 7.82 & $97.8 \pm 1.02$ \\
\hline & $\begin{array}{c}12.0 \\
4.0\end{array}$ & $\begin{array}{l}12.45 \\
4.09\end{array}$ & $\begin{array}{l}103.8 \pm 1.58 \\
102.3 \pm 1.55\end{array}$ \\
\hline \multirow[t]{2}{*}{ B } & 8.0 & 8.44 & $105.5 \pm 1.30$ \\
\hline & $\begin{array}{l}12.0 \\
40.0\end{array}$ & $\begin{array}{l}12.79 \\
38.25\end{array}$ & $\begin{array}{l}106.6 \pm 1.11 \\
95.62 \pm 0.52\end{array}$ \\
\hline \multirow[t]{2}{*}{$\mathrm{C}$} & 80.0 & 79.65 & $99.56 \pm 1.25$ \\
\hline & 120.0 & 123.8 & $103.2 \pm 1.60$ \\
\hline
\end{tabular}

*Mean value of three determinations.

Recovery study

To further assess the accuracy of the methods, recovery experiments were performed by applying the standard-addition technique. The recovery was assessed by determining the agreement between the measured standard concentration and added known concentration to the sample. The test was done by spiking the pre-analysed tablet powder with pure OFX at three different levels $(50,100$ and $150 \%$ of the content present in the tablet powder (taken) and the total was found by the proposed methods. Each test was repeated three times. In all the cases, the recovery percentage values ranged between $98.7-102.6 \%$ with relative standard deviation in the range $0.88-1.5 \%$. Closeness of the results to $100 \%$ showed the fairly good accuracy of the methods. The results are shown in Table 7. 
Table 7. Results of recovery study using standard addition method.

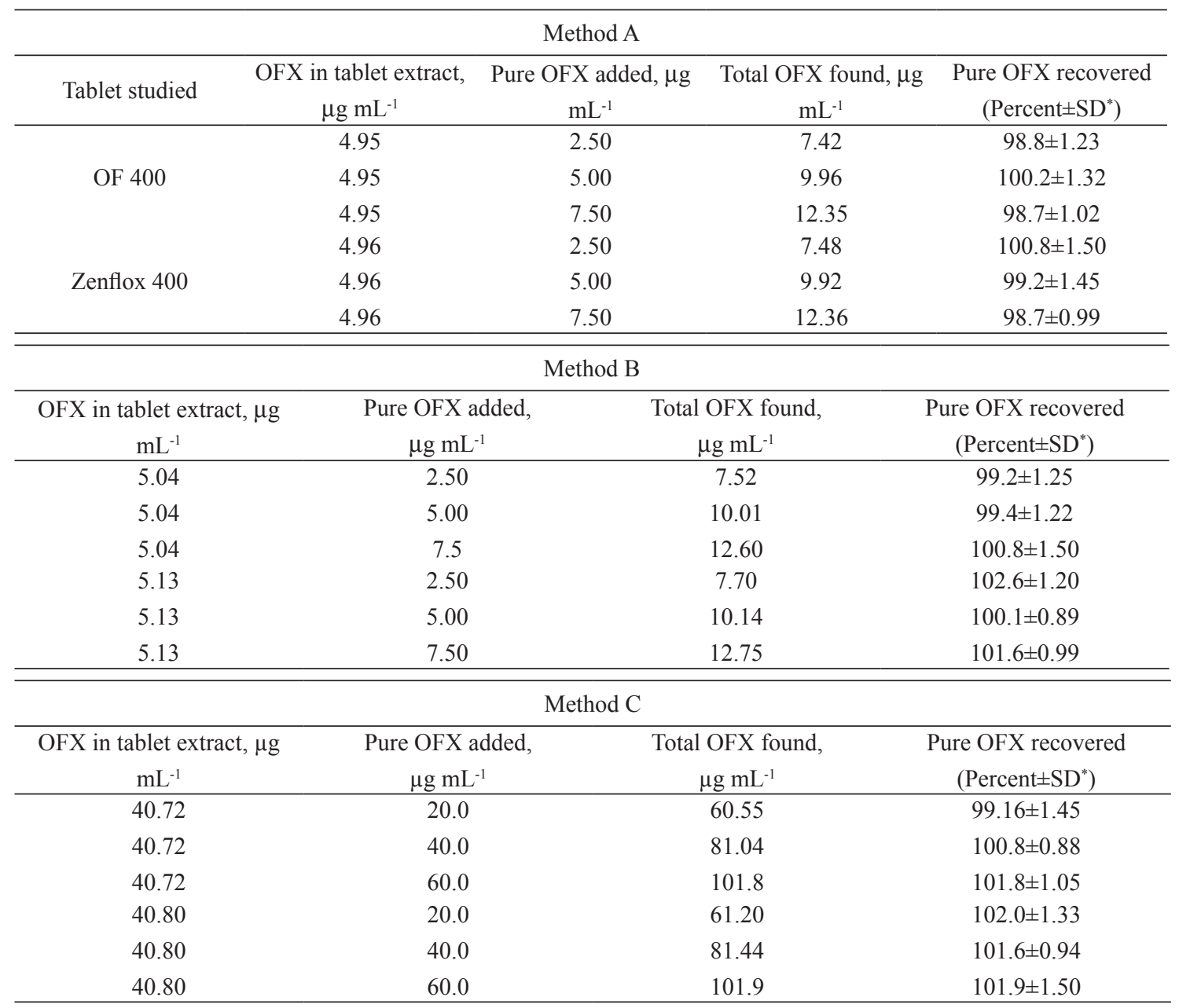

*Mean value of three determination.

\section{Conclusion}

Three simple, rapid, accurate and precise, and cost-effective spectrophotometric methods were developed and validated for the determination of OFX in pharmaceuticals and in spiked human urine. The proposed spectrophotometric methods do not require any expensive equipment and specialized technicians when compared alongside HPLC, chemiluminescence, FIA, electroanalytical and bioassay techniques. Besides, other characteristics of these methods are short time required for performance and ease of handling. The proposed UV methods are more sensitive than many repor- ted methods, require no additional reagents or organic solvents. Though the sensitivity of method $\mathrm{C}$ is less when compared to method $\mathrm{A}$ and method $\mathrm{B}$, the OFX-iron(III) complex in sulphuric acid medium has suitable characteristics for the spectrophotometric determination of OFX. The visible spectrophotometric method is the simplest of all the reported spectrophotometric methods in terms reagents used, optimal conditions employed, since no heating or extraction step is involved. The procedure has been demonstrated to be independent of $\mathrm{pH}$ of the reaction medium unlike the reported method using iron(III) nitrate which employs buffer medium. The proposed methods are highly 
precise compared to most reported methods where the precision is affected by critical experimental variables. The absence of any crucial experimental variable makes the present methods more accurate than many reported methods. The methods are useful for the quality control and routine analysis of OFX in pharmaceuticals since there is no interference from the common excipients that might be found in commercial preparations. Also, these methods allow determination of OFX in human urine samples in the physiological concentration range obtained after the usual therapeutic dose of OFX has been administered.

\section{Acknowledgement}

Authors thank Cipla India Ltd, India, for gifting pure OFX. KBV thank the authorities of the University of Mysore, Mysore, for permission and facilities.

\section{References}

K. Sat, U. Matsura, M. Inone, T. Ueno, Y. Osada, H. Ogawa, M. Mitshuhashi, Antimicrob. Agents Chemother. 22 (1982) 548.

F.A. El-Yazbi, Spectrosc. Lett. 25 (1992) 279.

Q.J. Gong, J.L. Quiao, L.M. Du, C. Dong, Talanta 53 (2000) 359 .

A. Le Coguic, R. Bidault, R. Farinotti, A. Dauphin, J. Chromatogr. 434 (1988) 320.

O. Okazaki, H. Aoki, H. Hakusui, J. Chromatogr. 563 (1991) 313.

G. Carlucci, P. Mazzeo, T. Fantozzi, Anal. Lett. 26 (1993) 2193.

V.M. Shinde, B.S. Desai, N.M. Tendolkar, Indian Drugs 35 (1998) 715.

U.P. Halkar, P.B. Ankalkope, Indian Drugs 37 (2000) 585.

M. S. Ali, M. Ghori, A. Saeed. J. Chromatogr. Sci. 40 (2002) 429.

A.J.N. Groenveld, J.R.B. Brouwers. Pharm. World Sci. 8 (1986) 79-84.

R.R. Kalta, R. Sharma, S.C. Chaturvedi. Ind. J. Pharma. Sci. 70 (2008) 491-494.

K. P. Chan, K. On Chu, W. W-K. Lai, K.W. Choy, C.C. Wang, D. S-C Lam, C. P. Pang. Anal. Biochem. 353 (2006) 30-36.

T. Ohkubo, M. Kudo, K. Sugawara. Anal. Sci. 7 (1991) $741-$ 743.

Ecl. Quím., São Paulo, 34(4): 65 - 78, 2009
M.A. Gracia, C. Solans, A. Calvo, M. Royo, E. Hernandez, R. Rey, M.A. Bregante. Chrmatographia, 55 (2002) 431-434.

B. Srividya, R.M. Cardoza, P.D. Amin, Indian drugs, 40 (2003), 41-43.

S.W. Sun, A.L. Wu, J. Liq. Chromatogr. Relat. Technol. 22 (1999) 281.

C. Horstkoetter, G. Blaschke, J. Chromatogr. B 754 (2000) 169.

S.S. Zhang, H. Liu, Y.J. Wu, C.L. Yu, Analyst 126 (2001) 441.

A. Tamer, Anal. Chim. Acta. 231 (1990) 129.

M. Tuncel, Z. Atkosar, Pharmazie 47 (1992) 642.

G. Zhou, J. Pan, Anal. Chim. Acta. 307 (1995) 49.

M. Rizk, F. Belal, F. Aly, N. El-Enany, Talanta 46 (1998) 83.

J. Wu, H. Zhao, L. Wei, T.Z. Ai, X.Z. Dong, Fenxi Huaxue 29 (2001) 1106.

F. Paul, J.L Adcock, Anal. Chim. Acta. 541 (2005) 3.

S. Hanwen, L Liqing, C. Xueyan, Anal. Sci. 22 (2006) 1145.

Y Rao, Y Tong, X.R. Zhang, G. Luo, Baeyens, Willy, J. Fluoresc, 17 (2007) 481.

L. Yi, H. Zhao, S. Chen, L. Jin, D. Zheng, Z. Wu, Talanta 61 (2003) 403.

Y.D. Liang, J.F. Song, X.F. Yang, Anal. Chim. Acta 510 (2004) 21.

B. Li, Z. Zhang, L. Zhao, Ch. Xu, Talanta 57 (2002) 765.

S.E. Lisiane da, E.S.S. Elfrides. J. Pharm. Biomed. Anal, 27 (2002) 91.

British Pharmacopeia. Vol III Her Majesty's Stationery office, London, (2003) p 1357.

United States Pharmacopoeia XXII, National Formulary XVII, Rockville, USA Convention, (1990) p 912.

European Pharmacopoeia. EDQM, Council of Europe, Strasbourg, France. 5 (2005) p 2131.

P.U. Patel, B.N. Suhagia, M.M. Patel, G.C. Patel, G.N. Patel, Indian Pharmacist, 6 (2007) 59.

Y.M. Issa, F.M. Abdel-Gawad, M.A. Abou Table, H.M. Hussein, Anal. Lett. 30 (1997) 2071.

C. S. P. Sastry, Kolli Rama Rao, D. Siva Prasad, Talanta, 42 (1995) 311.

C.J. Eboka, S.O. Aigbavboa, J.O. Akerele, J. Antimicrob. Chemother. 39 (1997) 639.

S.C. Mathur, Y. Kumar, N. Murugesan, Y.K.S. Rathore, P.D. Sethi, Indian Drugs, 29 (1992) 376.

M.S. Soledad, M.I. Albero, C. Sanchez-Pedreno, M.S. Abuherba, Eur. J. Pharm. Biopharm. 61 (2005) 87.

C.S.P. Sastry, K.R. Rao, D.S. Prasad, Indian Drugs, 32 (1995) 172.

D. Lee, H. Han, K. Kim, W. Park, J.Cho. J.Kim, J. Pharm. Biomed. Anal. 12 (1994) 157.

Douglas, A. S and Donald. M. W. 1971. "Principels of Instrumental Analysis," Holt, Rinheart and Winston, New York, p 104.

Erk N Anal. Lett. 36 (2003) 1183. 
Zavis, H., Ludvik, D., Milan, K., Ladislaw, S. and Frantisck, V. Handbook of Organic Reagents in Inorganic Analysis. Translated by Stanislav, K, Dr. Chalmers (The Series and Translation Editor: University of Aberdem, Ellis Horwood Limited, Chichester, A Division of John Wiley \& Sons IC, New York, London, Sydney. Toronto. (1976) p 364.

International Conference on Hormonisation of Technical Requirements for Registration of Pharmaceuticals for Human Use, ICH Harmonised Tripartite Guideline, Validation of Analytical Procedures: Text and Methodology Q2(R 1), Complementary Guideline on Methodology dated 06 November 1996, incorporated in November 2005, London.

Inczedy, J., Lengyel, T. and Ure, A.M. 1998. IUPAC Compendium of Analytical Nomenclature : Definitive Rules, Blackwell Science Inc., Boston. 